\title{
Reducing Distance Learners' Attrition Rate at the University of Cape Coast: Tutors'/Students' Perception
}

\author{
Clara Akuamoah-Boateng (Mrs.) (Corresponding Author) \\ Centre for Continuing Education \\ University of Cape Coast, Central Region - Ghana \\ Tel:+233-3321-36946/7Ｅ-mail:cakuamoahboateng@yahoo.co.uk \\ Kankam Boadu \\ Department of Arts and Social Sciences Education \\ University of Cape Coast, Central Region - Ghana \\ Tel:+233-244708348Ｅ-mail:kankam21265@gmail.com
}

Accepted: April 25, 2013 Published: July 31, 2013

Doi:10.5296/ijld.v3i3.4068 URL: http://dx.doi.org/10.5296/ijld.v3i3.4068

\begin{abstract}
The goal of Distance Education in Ghana is to make quality education, especially at the tertiary level, more accessible and relevant to meeting the human resource needs of the country. This is to improve performance as well as the quality of lives of Ghanaians. This dream can only be realised if students enrolled on the programmes graduate on schedule. Students' enrollment on the Distance Education Programme at the University of Cape Coast (UCC) currently is over 24,000. However, not every student enrolls on the programme graduates on schedule for various reasons. This paper examines tutors' and students' perception on the attrition rate of distance learners. Survey research method was used to gather data and analysis done using frequency count, simple percentages, mean and standard deviation. Factors identified as causes of attrition and measures to reduce the problem were significant as perceived by tutors and learners. However, this paper concludes that the complexity of causes of attrition and measures to reduce it allow for few practical or readily applied solution. Most of the significant causes were evolutionary issues that can be resolved as time goes on through improvement in technology, effective course designing, better understanding of learner characteristics and appropriate learner support systems. Some recommendations were made as interim measures to help reduce the high attrition among UCC distance learners.
\end{abstract}

\section{Introduction}

Distance education, as an alternative to face-to-face instruction, has witnessed steady growth in higher education since it's beginning in the mid 1800s. This growth is evidenced by the fact that in 1990 nearly 30 percent of all adult students in the United States were receiving education in some distance format (Roberts, 2006). The influx of adults taking distance education course has occurred in part because of the proliferating demand of our technological society and the complexity of modern life. Before the distance education programme of the University of Cape Coast in 2001, the university had a total enrolment of 3,584 students on its conventional programmes. As of 2010, the distance education programme alone had a total enrolment of about 24,000 students pursuing diploma and degree programmes in Basic Education, Commerce and Management Studies (Sam-Tagoe, Akuamoah-Boateng \& Brown, 2010). 
Society demands for lifelong learning, employment and family responsibilities calls for adults to seek forms of education other than traditional face-to-face instruction (Moxley, 2006). Distance education provides adults with the opportunity for formal education while allowing for flexible scheduling. However it appears the emergence of distance education at the University of Cape Coast is accompanied by the problem of high attrition rates.

In an attempt to find out reasons for non-completion of programmes by some students on distance learning programme and, evidence for the high attrition rate, numerous studies have centered on the application of a variety of traditionally based theoretical models on distance education setting (Tinto, 1982). However, there has not been any empirical study on reducing the attrition based on tutors'/students' perspective at the University of Cape Coast. There is therefore, the critical need to examine tutors'/students' perception on the attrition rate of distance learners at the University of Cape Coast, Ghana. This is necessary in order to give members of the Faculty of Education and counselors the opportunity to interact with students who are possible non-completers to redeem themselves. It will also help them to make careful placement and enhance review techniques, particularly in the courses, and to further assist students to prolong their academic career.

\subsection{Statement of the Problem}

Higher Education has an important role to play in national development and in keeping academic pursuits and augmenting of knowledge (Benakani, 2009). Distance education students are perceived to have higher attrition rates than conventional students (Phipps, \& Merisots, 1999) although there has been much debate over the causes of attrition.

The distance education programme at the University of Cape Coast has provided access to higher education for many people in Ghana. Before the advent of distance education in 2001, the University of Cape Coast had a total enrolment of about 3,584 students on its conventional programmes. The distance education programme alone as at 2010 has increased its enrollment tremendously from 10,543 in 2001 to 54,707 in 2010 (Akuamoah-Boateng, Sam-Tagoe \& Brown, 2010).

However, evidence from the Assessment Unit of the Centre for Continuing Education, UCC indicates that not all students who enroll on the programme are able to graduate on time and others do not graduate at all due to several reasons. For instance in 2001 out of 860 diploma in basic education students, 143 could not graduate; in 2002, out of 2,868 students, 263 could not graduate; in 2003, and in 2004, out 3,161 students, 459 could not graduate. This trend suggests that there appear to be some problems associated with the completion rates of students on the distance mode of education at the University of Cape Coast. Even though not all students are able to graduate on schedule, there has not been any known empirical research on the causes and measures to reduce attrition rate on the distance education programme at the University of Cape Coast. This gap needs to be filled, hence the study.

\subsection{Research Questions}

The study was guided by the following research questions:

1. What are demographic characteristics of distance learners?

2. What factors do distance learners perceive as causes of high attrition rate on their programme?

3. How do course tutors view distance learners' high attrition rate?

4. What practical measures could be put in place to reduce attrition rate of distance learners at University of Cape Coast? 


\section{Review of Literature}

Review of literature offers an overview of other research studies related to this study as predictors of distance learners' attrition. Distance learning is an excellent method of reaching the adult learner. The competing priorities of work, home and school calls for a higher degree of flexibility in distance learning programmes. The structure of distance learning programmes gives the adult learner the greatest possible control over time, place and pace of study. However, the distance mode of learning is without problems Carr (2000). Most distance programmes are beset with higher attrition rate. Dagger and Wade (2004) agues that with the growth of distance education over the years there has been a problem of exceedingly high attrition rate of learners in most distance learning institutions worldwide. Distance learners' attrition and completion rate in any distance learning institution should get continuous attention from researchers and providers.

The success of such programmes depend largely on extensive research that will provide information that may help in developing better and appropriate student support services to improve the effectiveness and efficacy of programme delivery and success Thompson (1979). Huang (2004) concurs when he notes that the issue of attrition in distance learning programmes is important in assessing the relative effectiveness of the cost of distance learning compared to traditional classroom-based. He further argues that attrition issues if not checked affects educational planning and the value of investment in distance learning, educational institutions, corporations and government agencies. Another important reason given by Huang is that research findings on distance learners attrition rate will help in determining the approaches to increase access, learning outcomes and the perceived value and credibility of distance learning programmes and qualifications.

Lowe (2005) recognizing the complexity of attrition issues in distance learning, claim the problem reflect partly on the inability of distance learning institutions to provide learners with adequate relational and academic support services. He further agues that distance learning institutions has the higher ethical obligation in addressing attrition problems. However, there appears to be no empirical data on distance learners' attrition rates currently at the University of Cape Coast.

\subsection{Characteristics of Distance Learners}

To understand the attrition rate within the context of distance learning, it is essential to understand the characteristics of adult learners. The intentions of adults to learn have been identified by Knowles, Holton and Swanson (1998) as follows:

- The need to know: Adults need to know why they need to learn something before understanding to learn it.

- The learner's self-concept: Adults have a self-concept of being responsible for their own decisions, for their own lives. Once they have arrived at that self-concept, they develop a deep psychological need to be seen by others and treated by others as being capable of self-direction.

- The role of the learner's experience: Adults come into educational activity with both greater volume and a different quality of experience from youth. These experiences lead to diverse audiences in any adult group setting.

- Readiness to learn: Adult learners become ready to learn those things they need to know and be able to do in order to cope effectively with their real life situations.

- Orientation to learning: Adult learners are life-centered in their orientation to learning. They are motivated to devote energy to learn something to the extent that 
they perceive that it will help them perform tasks or deal with problems that they are confronted with in their life situations.

- Motivation: While adults are responsive to some external motivators (better jobs, promotions, and higher salaries) the most potential motivations are internal pressures (the desire for increased job satisfaction, self-esteem, quality of life). Motivation may be blocked by an adult's negative self-concept as a student, time constraints and programs that violate principles of adult learning (Knowles, Holton and Swanson, 1998, pp. $55-61$ ).

- The knowledge of distance education learners background profile, according to Garrison (1987) will help to better understand how to design and deliver distance education programmes.

\subsection{Causes of Distance Learners' Attrition}

Research has shown that attrition cannot and should not be attributed to one factor, as the reasons for withdrawal are complex and interrelated Bernard \& Amundsen (1989) Morgan \& Tam, 1999). Barriers to learning and participation can be classified under three headings such as situational, institutional and dispositional (Cross, 1981). Situational barriers include poor learning environment, lack of time due to work or home responsibilities and geographic location. Institutional barriers include cost, problems with institutional procedures, course scheduling, course availability and tutorial assistance; dispositional barriers include lack of a clear goal, stress of multiple roles, time management, learning styles differences, psychological, social and economic factors.

The potential for a student to successfully complete any distance learning programme also depends upon specific student characteristics that have been identified as indicators for potential success:

- Being a self-starter

- Having self-discipline

- Being knowledgeable of the technology requirement of specific formats

- Being able to meet other students in a virtual environment (Keegan, 1986).

Factors such as age, marital status, educational level, and gender, which are particular to an individual context, have also been identified as causes of attrition among distance learners (Morgan \&Tam, 1999). Other factors that have been investigated as causes of attrition included number of courses and sources of financial aid (Parker, 1999). Another important variable for students' progress is the impact of the part-time statuses of most adult learners in distance education. Generally speaking, part-time students have higher attrition rates than full-time students. As students are the ones who perform the study, their entry qualification will certainly affect their study outcomes. Research results have shown that the background characteristics of students are significant factors affecting their completion rate on a programme (Rovai, 2003) Phythian and Clement (1980) reported job, domestic pressure and course content being too hard or long as the three main reasons for dropouts from third year-level mathematics courses in open university. Rekkedal (1983) reported a number of reasons for learners' dropout from the NKL school in Norway, such as lack of time, job commitments, changed career plans, economic reasons, illness, unsatisfactory living or study conditions and personal reasons.

Oztok and Brett (2011) stressed that dropout is a phenomenon caused by learners' characteristics (educational background, personality, motivation, aptitude and so on) and life circumstances (occupation, relationship with family and peer group, health and so on). 
A research conducted by Thompson (1997) showed that the majority of students reported that work; family and study commitments were the main reasons for their withdrawal. Some other researchers reported psychological reasons for dropouts such as feeling of inadequacy, distress, and examination anxiety as reasons for dropping out (Fan \& Chan, 1997). Difficult course content and learning environment have also been identified as important reasons for attrition (Chyung, Winieki \& Fenner, 1998). It is clear from the literature that many issues accounts for the causes of high attrition rate which need to be looked at in this study.

\section{Methodology}

The study adopted descriptive survey design, using simple random sampling technique through computer lottery method to select a sample of 360 students from a population of 1,985 final year Education students who have not been able to graduate for various reasons. These students were contacted through their cell phone numbers to meet at their various study centre to respond to the questionnaire. Out the Course tutor population of 1,300 in the entire ten regions of Ghana, 100 basic education course tutors were randomly selected.

Data was gathered at all the Regional study centres located at Ashanti, Brong Ahafo, Central, Eastern, Upper West, Northern, Upper East and Volta Regions of Ghana. Each of the ten regions had a Regional Resident Tutor, Coordinators and Course Tutors. The Study Centre Coordinators were briefed about the essence of the study and the instruments were given to them to administer to the students at the centres. Final year students were used because they have been on the programme long enough to have experienced some of the causes of attrition in the programme. Two sets of questionnaire one for the course tutors and one for students were designed to elicit relevant information for the study. In all, 75 (75\%) course tutors and 285 (79\%) students returned copies of their questionnaire. Data gathered were analyzed using Statistical Package for the Social Sciences (SPSS) in accordance with the research questions. The investigators concentrated on the distance learners who actually dropped out of their programmes and those who have problems with some of their courses.

\subsection{Presentation of Results and Discussion of Research Findings}

3.1.1 Demographic Characteristics of Students

The demographic characteristics of students were sought in order to determine whether they have any influence on their attrition rate. Information obtained is shown in Table 1.

Table 1: Demographic profile of students

\begin{tabular}{llcc}
\hline Variables & Sub-scales & Number $(\mathrm{N})$ & Percentage (\%) \\
\hline Sex & Male & 185 & 64.9 \\
& Female & 100 & 35.1 \\
Age & Below 18 & & \\
& $18-22$ & - & - \\
\hline
\end{tabular}




\begin{tabular}{llll}
\hline & $23-27$ & 135 & 47.4 \\
& Above 27 & 150 & 52.6 \\
Programme of study & Psychology of Education & 140 & 49.1 \\
& Post Diploma in Education & 85 & 29.8 \\
& Diploma in Education & 60 & 21.1 \\
Employment status & Employed & 265 & 93 \\
& Unemployed & 20 & 7 \\
Marital Status & Married & 85 & 29.8 \\
& Single & 200 & 70.2 \\
& Divorced/Separated & - & - \\
\hline
\end{tabular}

Table 1 presents the demographic characteristics of the respondents for the study. In terms of gender distribution, 185 (64.9\%) were males while 100 (35.1\%). This implies that males exceed females in terms of pursuing distance education programme in the University. Also, it can be seen that majority, $150(52.6 \%)$ of the respondents were above the age of 27 , while 135 $(47.4 \%)$ were between the ages of $23-27$. Also, it can observed that, majority 265 (93\%) were employed while $20(7 \%)$ were unemployed. In terms of marital status, 85 (29.8\%) were married while $200(70.2 \%)$ were single. This seems to suggest that although the distance education programme is for all groups of people, most of the students pursing it are not married.

\subsubsection{Demographic Characteristics of Tutors}

The demographic characteristics of Course tutors were sought in order to determine the characteristics of tutors responding to the attrition rate. Information obtained is shown in Table 2.

Table 2: Demographic Profile of Tutors

\begin{tabular}{llll}
\hline Variables & Sub-scales & Number $(\mathrm{N})$ & Percentage $(\%)$ \\
\hline Sex & Male & 52 & 69.3 \\
& Female & 23 & 30.7 \\
Age & Below 30 & & \\
& $31-35$ & 4 & 5.3 \\
& $36-40$ & 14 & 18.6 \\
& $41-45$ & 20 & 26.7 \\
& $46-50$ & 24 & 32 \\
& Above 50 & 8 & 10.7 \\
& & 5 & 6.7 \\
Academic Qualification & First degree & & \\
& Masters degree & 40 & \\
& PhD & 18 & 24.3 \\
& Others & 2 & 2.7 \\
Teaching experience & $1-5$ years & 15 & 20 \\
\hline
\end{tabular}




\begin{tabular}{lll}
$6-10$ years & 12 & 16 \\
$11-15$ years & 15 & 20 \\
$16-20$ years & 8 & 10.7 \\
Above 20 years & 6 & 8 \\
\hline
\end{tabular}

Table 2 presents the demographic characteristics of the tutors of distance education programme used for the study. In terms of gender distribution, it can be observed from Table 2 that, out of the 75 tutors used for the study, $52(69.3 \%)$ were males while $23(30.7 \%)$ were females. This implies that most of the tutors teaching in the distance education programme are males. Also, it could be seen that majority, $24(32 \%)$ of the respondents were between the ages of $41-45$, while $20(26.7 \%)$ were between the $36-40$ and 40 . However, the table also indicates that only $4(5.3 \%)$ were below the age of 30 .

It could be further observed from Table 2 that, 40 (53.3\%) of the respondents were first-degree holders in various fields of study, 18 (24\%) have masters degrees while $2(2.7 \%)$ have PhD. Also, 15 (20\%) indicated that they have other forms of academic qualification such as Diploma in Education and other professional qualifications. In terms of teaching experience, it could be observed that, majority $34(45.3 \%)$ of the tutors have taught for $1-5$ years, this is followed by $15(20 \%)$ who have taught for $11-15$ years. However, those with over 20 years of teaching experience were $6(8 \%)$. This is an indication that, all tutors for the distance education programme have some level of teaching experience that is very important. This means that, their professional competency levels are very high and they are well grounded in the pedagogical aspects of the teaching profession.

\subsubsection{Causes of Distance Learners attrition}

The study sought to find out the causes of distance learners attrition rate. Nineteen items in the instrument sampled students' view on the causes of attrition. Information obtained is shown in Table 3. Mean ranges: Agree (A) - 3; Undecided (U) - 2; and Disagree (D) - 3 .

Mean of Means $=2.53$; Mean of Standard Deviation $=0.76$

Table 3: Students' Views on Causes of Distance Learners' Attrition

\begin{tabular}{|c|c|c|c|c|c|c|}
\hline No. & Statement & $\begin{array}{c}\text { A } \\
\mathrm{N}(\%)\end{array}$ & $\begin{array}{c}\mathrm{U} \\
\mathrm{N}(\%)\end{array}$ & $\begin{array}{c}\mathrm{D} \\
\mathrm{N}(\%)\end{array}$ & M & SD \\
\hline 1 & $\begin{array}{l}\text { Academic achievement before entry predicts } \\
\text { attrition }\end{array}$ & $175(61.4)$ & $55(19.3)$ & $55(19.3)$ & 2.62 & .80 \\
\hline 2 & $\begin{array}{l}\text { Whether the initial course is the first } \\
\text { preference of students also has a significant } \\
\text { impact on course attrition }\end{array}$ & $170(59.6)$ & $80(28.1)$ & $35(12.3)$ & 2.47 & .70 \\
\hline 3 & $\begin{array}{l}\text { Student aspirations in undertaking particular } \\
\text { courses and the degree of 'fit' between such } \\
\text { aspirations and what courses deliver } \\
\text { influences attrition rate }\end{array}$ & $220(77.2)$ & $55(19.3)$ & $10(3.5)$ & 2.74 & .51 \\
\hline 4 & $\begin{array}{l}\text { The quality of teaching and the teaching } \\
\text { staff influences attrition rate }\end{array}$ & $195(68.4)$ & $45(15.8)$ & $45(15.8)$ & 2.83 & .75 \\
\hline 5 & $\begin{array}{l}\text { The economic position of the students } \\
\text { themselves has also been linked to their risk } \\
\text { of leaving study. }\end{array}$ & $180(63.2)$ & $30(10.5)$ & $75(26.3)$ & 2.77 & .87 \\
\hline 6 & $\begin{array}{l}\text { Distance education may cause a sense of } \\
\text { isolation that weakens the motivation, which }\end{array}$ & $110(38.6)$ & $40(14)$ & $135(47.4)$ & 1.91 & .92 \\
\hline
\end{tabular}


is an important reason for student attrition

7 A social environment where the student

$160(56.1) \quad 65(22.8) \quad 60(21.1) \quad 2.35$

experiences security, takes responsibility and is inspired, produces positive learning effects and also reduces student attrition

8 The student's ability to cooperate in a learning community is crucially important

$\begin{array}{llll}185(64.9) & 65(22.8) & 35(12.3) & 2.88\end{array}$ .70 for the decision to drop out or complete the studies

9 The student's previous education, study $\begin{array}{lllll}185(64.9) & 50(17.5) & 50(17.5) & 2.47 & .78\end{array}$ experience and motivation are all important factors influencing attrition

10 Distance education students who have their own families are somewhat more likely to drop out.

11 Motivation and support from family and friends are factors which increase the likelihood that a student will complete the education

12 Communication, especially with the teacher, is an important ingredient in supported distance education

13 There are great deficiencies in the communication between teacher and student, which should have a greater emphasis on the role of the teacher as a facilitator of dialog and active participation

14 Other drop out reasons are simultaneous work and studies or parallel studies

15 Conflict between the study and other commitments in family, social or working life as one of the important reasons for dropout

16 Psychological reasons for dropout like, feeling of inadequacy, distress, lack of confidence and examination anxiety

17 Lengthy and difficult course content

18 Loss of interest

$\begin{array}{lllll}115(40.4) & 40(14) & 130(45.6) & 1.95 & .93\end{array}$

$\begin{array}{lllll}235(82.5) & 30(10.5) & 20(7) & 2.75 & .57\end{array}$

$\begin{array}{lllll}220(77.2) & 35(12.3) & 30(10.5) & 2.67 & .66\end{array}$

$\begin{array}{lllll}165(57.9) & 30(10.5) & 90(31.6) & 2.96 & .91\end{array}$

19 Course content not relevant to present career

$\begin{array}{lllll}205(71.9) & 45(15.8) & 35(12.3) & 2.60 & .70 \\ & & & & \\ 215(75.4) & 15(5.3) & 55(19.3) & 2.56 & .80 \\ & & & & \\ & & & & \\ 200(70.2) & 45(15.8) & 40(14) & 2.56 & .73 \\ & & & & \\ & & & & \\ 205(71.9) & 35(12.3) & 45(15.8) & 2.86 & .75 \\ 170(59.6) & 65(22.8) & 50(17.5) & 2.72 & .77 \\ & 40(14) & 200(70.2) & 1.46 & .75 \\ 45(15.8) & & & & \end{array}$

Results presented in Table 3 shows a mean of means and mean of standard deviations as $(\mathrm{M}=$ $2.53, \mathrm{SD}=0.76$ ). These figures, according to the scale used for the analysis indicate that, on the whole, the students generally agreed that the 19 factors listed were possible causes of distance education students' attrition rate. It means that, a lot needs to be done if administrators of the distance education programme want to reduce the level of attrition. This is because the nature of the responses given indicates that a lot of factors determine whether a distance learner drops out or completes a programme. The standard deviation $(\mathrm{SD}=0.76)$ shows a relatively high consensus about the mean of means value $(\mathrm{M}=2.53)$. This means that the reasons why distance learners drop out of their programmes over a certain period of time are many as attested by the 
students themselves. Interestingly, the students seem to consider motivation and support from family and friends as factors, which increase the likelihood that students complete or leave their programmes.

\subsubsection{Tutors' Views on Causes of Distance Learners' Attrition}

The tutors' views were also sought on the causes of distance learners' attrition. The reason is that, the tutors might have interacted with the friends of the dropouts or the dropouts themselves. Mean ranges: Agree (A) - 3; Undecided (U) - 2; and Disagree (D) - 1.Mean of Means $=2.60$; Mean of Standard Deviation $=0.76$. Table 4 shows information gathered from the tutors.

Table 4: Tutors' Views on Causes of Distance Learners' Attrition

\begin{tabular}{|c|c|c|c|c|c|c|}
\hline No. & Statement & $\begin{array}{c}\text { A } \\
\mathrm{N}(\%)\end{array}$ & $\begin{array}{c}\mathrm{U} \\
\mathrm{N}(\%)\end{array}$ & $\begin{array}{c}\mathrm{D} \\
\mathrm{N}(\%)\end{array}$ & $\mathrm{M}$ & SD \\
\hline 1 & $\begin{array}{l}\text { Academic achievement before entry predicts } \\
\text { attrition }\end{array}$ & $47(62.7)$ & $15(20)$ & $13(17.3)$ & 2.95 & .78 \\
\hline 2 & $\begin{array}{l}\text { Whether the initial course is the first } \\
\text { preference of students also has a significant } \\
\text { impact on course attrition }\end{array}$ & $44(58.7)$ & $21(28)$ & $10(13.3)$ & 2.45 & .72 \\
\hline 3 & $\begin{array}{l}\text { Student aspirations in undertaking particular } \\
\text { courses and the degree of 'fit' between such } \\
\text { aspirations and what courses deliver } \\
\text { influences attrition rate }\end{array}$ & $57(76)$ & $15(20)$ & $3(4)$ & 2.72 & .53 \\
\hline 4 & $\begin{array}{l}\text { The quality of teaching and the teaching } \\
\text { staff influences attrition rate }\end{array}$ & $51(68)$ & $14(18.7)$ & $10(13.3)$ & 2.55 & .72 \\
\hline 5 & $\begin{array}{l}\text { The economic position of the students } \\
\text { themselves has also been linked to their risk } \\
\text { of leaving study. }\end{array}$ & $47(62.7)$ & $9(12)$ & $19(25.3)$ & 2.37 & .87 \\
\hline 6 & $\begin{array}{l}\text { Distance education may cause a sense of } \\
\text { isolation that weakens the motivation, which } \\
\text { is an important reason for student attrition }\end{array}$ & $30(40)$ & $11(14.7)$ & $34(45.3)$ & 1.94 & .93 \\
\hline 7 & $\begin{array}{l}\text { A social environment where the student } \\
\text { experiences security, takes responsibility } \\
\text { and is inspired, produces positive learning } \\
\text { effects and also reduces student attrition }\end{array}$ & $40(53.3)$ & $19(25.3)$ & $16(21.3)$ & 2.82 & .81 \\
\hline 8 & $\begin{array}{l}\text { The student's ability to cooperate in a } \\
\text { learning community is crucially important } \\
\text { for the decision to drop out or complete the } \\
\text { studies }\end{array}$ & $46(61.3)$ & $19(25.3)$ & $10(13.3)$ & 2.88 & .72 \\
\hline 9 & $\begin{array}{l}\text { The student's previous education, study } \\
\text { experience and motivation are all important } \\
\text { factors influencing attrition }\end{array}$ & $47(62.7)$ & $14(18.7)$ & $14(18.7)$ & 2.74 & .79 \\
\hline 10 & $\begin{array}{l}\text { Distance education students who have their } \\
\text { own families are somewhat more likely to } \\
\text { drop out. }\end{array}$ & $32(42.7)$ & $12(16)$ & $31(41.3)$ & 2.91 & .92 \\
\hline 11 & $\begin{array}{l}\text { Motivation and support from family and } \\
\text { friends are factors which increase the } \\
\text { likelihood that students will complete their }\end{array}$ & $61(81.3)$ & $10(13.3)$ & $4(5.3)$ & 2.76 & .54 \\
\hline
\end{tabular}


education

12 Communication, especially with the teacher, 57(76) is an important ingredient in supported distance education

13 There are great deficiencies in the communication between teacher and student, which should have a greater emphasis on the role of the teacher as a facilitator of dialog and active participation

14 Other drop out reasons are simultaneous work and studies or parallel studies

15 Conflict between the study and other commitments in family, social or working life as one of the important reasons for dropout

16 Psychological reasons for dropout like, feeling of inadequacy, distress, lack of confidence and examination anxiety

17 Lengthy and difficult course content

18 Loss of interest

$\begin{array}{llll}57(76) & 11(14.7) & 7(9.3) & 2.67 \\ 45(60) & 9(12) & 21(28) & 2.82\end{array}$

$\begin{array}{lclll}55(73.3) & 12(16) & & 2.63 & .67 \\ & & 8(10.7) & & \\ 57(76) & 5(6.7) & 13(17.3) & 2.59 & .77 \\ & & & & \\ & & & & \\ 50(66.7) & 13(17.3) & 12(16) & 2.51 & .76 \\ & & & & \\ 53(70.7) & 10(13.3) & 12(16) & 2.55 & .76 \\ 44(58.7) & 17(22.7) & & 2.62 & .79 \\ & & 14(18.7) & & \\ 12(16) & 11(14) & 52(69.3) & 1.97 & .76\end{array}$

Analysis of tutors' view on causes of attrition shows, mean of means and mean of standard deviations as $(\mathrm{M}=2.60, \mathrm{SD}=0.76)$. These figures according to the scale used for the analysis indicates that, in a whole, the tutors generally agree that the 19 factors listed are possible causes of distance learners attrition rate. It means that, some practical readily measures should be put in place as interim measures to address the problem of attrition. A standard deviation ( $\mathrm{SD}=$ $0.76)$ shows a relatively high consensus about the mean of means value $(M=2.60)$. This means that the general reasons why distance learners' dropout of their programmes over a certain period of time are many and varied as attested by the students themselves. Surprisingly, the most agreeable cause among the tutors was lack of motivation from family and friends just as what the students responded.

\subsubsection{Measures to reduce attrition rate}

The tutors and students views were elicited on measures to reduce the attrition rate of distance learners. Tables 5 and 6 respectively depict students and tutors views. Mean ranges students: Effective (E) - 3; Not Sure (NS) - 2; and Ineffective (IE) - 3. Mean of Means $=2.48$. Mean of Standard Deviation $=0.74$ : Mean ranges tutors: Effective $(\mathrm{E})-3$; Not Sure $(\mathrm{NS})-2$; and Ineffective $(\mathrm{IE})-3$. Mean of Means $=2.46$. Mean of Standard Deviation $=0.75$

Table 5: Students' View on Measures to Reduce Attrition of Distance Learners

\begin{tabular}{|c|c|c|c|c|c|c|}
\hline No. & Statement & $\begin{array}{c}E \\
N(\%)\end{array}$ & $\begin{array}{c}\mathrm{NS} \\
\mathrm{N}(\%)\end{array}$ & $\begin{array}{c}\mathrm{IE} \\
\mathrm{N}(\%)\end{array}$ & M & SD \\
\hline 1 & $\begin{array}{l}\text { Providing guidance in time management } \\
\text { through their core faculty and part-time } \\
\text { academic counselors }\end{array}$ & $200(70.2)$ & $30(10.5)$ & $55(19.3)$ & 2.51 & .80 \\
\hline 2 & Providing intense pre-entry counseling & $225(78.9)$ & $35(12.3)$ & $25(8.8)$ & 2.70 & .62 \\
\hline
\end{tabular}


$3 \quad$ Monitoring the counseling sessions and

$\begin{array}{lllll}225(78.9) & 30(10.5) & 30(10.5) & 2.68 & .65\end{array}$

evaluated assignments with tutor

comments

4 Providing more concrete guidance in

$205(71.9) \quad 35(12.3) \quad 45(15.8) \quad 2.56$

.75 writing Assignments

5 Introducing different types of assignments besides short answer and long answer types

6 Sending evaluated assignments to the

$\begin{array}{lllll}160(56.1) & 50(17.5) & 75(26.3) & 2.30 & .86\end{array}$ students in time

$\begin{array}{llll}190(66.7) & 50(17.5) & 45(15.8) & 2.51 \quad .75\end{array}$

7 Contacts between the core faculty and the

205(71.9) $\quad 45(15.8) \quad 35(12.3) \quad 2.60$ students may be increased using various communication technologies

8 Introducing more hands-on experience

$\begin{array}{lllll}175(61.4) & 55(19.3) & 55(19.3) & 2.42 & .79\end{array}$ for skill development

9 Teaching and learning materials should

$250(87.7) \quad 10(3.5) \quad 25(8.8) \quad 2.80$ be made available to students on time

10 Extend the duration of the courses to

$\begin{array}{llll}170(59.6) & 25(8.8) & 90(31.6) & 1.72\end{array}$ provide students with more time to complete the courses

Analysis was done to find out the nature of the responses given in terms of the measures that can be put in place to reduce distance learners attrition rate. In the view of the students, a mean of means and mean of standard deviations were computed; $(\mathrm{M}=2.48, \mathrm{SD}=0.74)$. These figures, according to the scale used for the analysis, indicate that the students generally agree that the 10 factors listed are possible means of reducing distance education students attrition rate. A standard deviation of ( $\mathrm{SD}=0.76$ ) shows a relatively high consensus about the mean of means value $(\mathrm{M}=2.48 \approx 2.50)$. The outstanding measure that the students $250(87.7 \%)$ responded to was making teaching/learning materials available on time.

\subsubsection{Tutors' views}

Table 6 presents tutors' views on the measures to reduce attrition rate in distance learning. Mean ranges are: Effective $(E)=3$; Not Sure $(\mathrm{NS})=2$; and Ineffective $(\mathrm{IE})=3$. Mean of Means=2.48 and Mean of Standard Deviation=0.74. M represents Mean SD represents Standard Deviation.

Table 6: Tutors' View on Measures to Distance Learners' Reduce Attrition Rate

\begin{tabular}{|c|c|c|c|c|c|c|}
\hline No. & Statement & $\begin{array}{c}E \\
N(\%)\end{array}$ & $\begin{array}{c}\mathrm{NS} \\
\mathrm{N}(\%)\end{array}$ & $\begin{array}{c}\mathrm{IE} \\
\mathrm{N}(\%)\end{array}$ & $\mathrm{M}$ & SD \\
\hline 1 & $\begin{array}{l}\text { Providing guidance in time management } \\
\text { through their core faculty and part-time } \\
\text { academic counselors }\end{array}$ & $52(69.3)$ & $9(12)$ & $14(18.7)$ & 2.51 & .79 \\
\hline
\end{tabular}




\begin{tabular}{|c|c|c|c|c|c|c|}
\hline 2 & Providing intense pre-entry counseling & $60(80)$ & $9(12)$ & $6(8)$ & 2.72 & .61 \\
\hline 3 & $\begin{array}{l}\text { Monitoring the counseling sessions and } \\
\text { evaluate assignments with tutor } \\
\text { comments }\end{array}$ & $58(77.3)$ & $8(10.7)$ & $9(12)$ & 2.65 & .69 \\
\hline 4 & $\begin{array}{l}\text { Providing more concrete guidance in } \\
\text { writing Assignments }\end{array}$ & $52(69.3)$ & $11(14.7)$ & $12(16)$ & 2.53 & .76 \\
\hline 5 & $\begin{array}{l}\text { Introducing different types of } \\
\text { assignments besides short answer and } \\
\text { long answer types }\end{array}$ & $41(54.7)$ & $13(17.3)$ & $21(28)$ & 2.27 & .88 \\
\hline 6 & $\begin{array}{l}\text { Sending evaluated assignments to the } \\
\text { students in time }\end{array}$ & $49(65.3)$ & $14(18.7)$ & $12(16)$ & 2.49 & .76 \\
\hline 7 & $\begin{array}{l}\text { Contacts between the core faculty and the } \\
\text { students may be increased using various } \\
\text { communication technologies }\end{array}$ & $53(70.7)$ & $13(17.3)$ & $9(12)$ & 2.59 & .70 \\
\hline 8 & $\begin{array}{l}\text { Introducing more hands-on experience } \\
\text { for skill development }\end{array}$ & $45(60)$ & $16(21.3)$ & $14(18.7)$ & 2.41 & .79 \\
\hline 9 & $\begin{array}{l}\text { Teaching and learning materials should } \\
\text { be made available to students on time }\end{array}$ & $65(86.7)$ & $3(4)$ & $7(9.3)$ & 2.77 & .61 \\
\hline 10 & $\begin{array}{l}\text { Extend the duration of the courses to } \\
\text { provide students with more time to } \\
\text { complete the courses }\end{array}$ & $22(29.3)$ & $7(9.3)$ & $90(61.3)$ & 1.68 & .90 \\
\hline
\end{tabular}

An analysis was done to find out the nature of the responses given in terms of what measures can actually be put in place to reduce distance learners' attrition rate. In the view of the tutors, a mean of means and mean of standard deviations were computed; $(\mathrm{M}=2.46, \mathrm{SD}=0.75)$. These figures, according to the scale used for the analysis indicate that, on a whole, the tutors generally agree that the 10 factors listed are possible means of reducing distance education students' attrition rate. A standard deviation $(\mathrm{SD}=0.75)$ shows a relatively high consensus about the mean of means value $(\mathrm{M}=2.46 \approx 2.50)$. The highest rated measure given by the tutors $65(86.7 \%)$ was the provision of teaching/learning materials on time.

\section{Discussion of Findings}

The study has revealed that most of the students pursuing distance learning are males. One wonders why education has been made accessible in Ghana through distance education yet women are still lagging behind men. It is not clear whether the socio-cultural practices that mitigate against African women in career development is still dominant. The fewer number of females also reflects in the number of course tutors in the distance learning. This finding runs counter to Adrah's (2000) findings in the then College of Education, Winneba where females students were found to be more than males.

On marital status, it has come out that majority of the students are single. This marital status of students may help the students concentrate on their books, as there will be no pressure from marital demands.

On the qualification of the tutors, it was revealed that majority of the tutors were first degree holders. This qualification is on the lower side since the requirement of lecturers at the University of Cape Coast is at least a second degree.

On the causes of higher attrition rate on distance learning, both students and tutors agree on the 19-point factors list as possible causes of distance education. These factors fall in line with the existing literature (Nash 2004; Perraton, 1992; Keegan, 1988; \& Brookfield, 1986). The 
respondents' highest rated cause being motivation from family and friends confirms what Brookfield (1986) noted that, the adults need a comfortable and supportive environment to ensure success in learning.

As to how the attrition rate can be reduced, tutors and students have rated providing teaching/learning materials, intense pre-entry counseling as well as monitoring the counseling sessions and evaluated assignment with tutor comments as the highest consideration to reduce attrition. Again, sending evaluated assignments to students on time was also seen as a crucial measure to reduce attrition. These measures confirm literature in this area, which includes pre-course orientations (Wojciechowski \& Palmer, 2005). While Minich (1996) contends that frequent contact with students is critical in reducing attrition, Nash (2004) reminds us "interactions can be time-consuming and difficult for faculty to sustain" (p. 2).

It has also emerged from the study that reasons why female distance education students would leave the programme are significantly different from the reasons why a male distance education student will also leave the programme.

\section{Summary and Conclusion}

The problem of attrition in distance learning programmes have been argued over by several researchers without any consistent conclusions about the magnitude of the problem or clear understanding of what can be done to solve the problem. In examining tutors' and distance learners' perception of the attrition rate of distance learners, this paper focused on the distinctive characteristics of adult learners, predictors of attrition and measures to reduce the problem. While the finding of this study offers a constellation of causes of attrition among UCC distance learners and some measures to reduce the problem, little can readily be done to ameliorate the situation. The complexity of the causes of attrition and measures to reduce it allow for few practical or readily applied solutions. In some instances, some causes may be evolutionary issues that may, in time be resolved through improvement in technology, more effective course design, better understanding of adult learner characteristics, good facilitation skills and effective learner support systems. One area where something can be done readily to reduce the high distance learners' attrition rate is early faculty contact where intense pre-entry counseling sessions are given thorough orientation in relational, academic, and other retention strategies to address the problem of attrition. Greater level of persistence may be achieved if learners are supported to anticipate, recognize and recover from cognitive burden they may experience as beginners. The issue of distance learners' attrition needs further research but it is believed that early faculty contact and thorough fresher's orientation will help reduce high rate of attrition as perceived by both tutors and students to improve retention and enhance learning outcomes of UCC distance learners. Attrition cannot be attributed to one cause but must be considers as coming from a combination of factors. This study has identified important important predictors of attrition in distance learning and has sifted out others that did show significant effects. The findings may prove to be of value to UCC distance learning providers, future researchers and institutions providing distance learning.

\section{Recommendations}

Based on the findings, the following interim measures are recommended to reduce the high attrition rate of UCC distance learners: 
- Efforts must be made by the Centre for Continuing Education to make it a norm to employ tutors who have at least second degree. Such tutors will be able to teach and encourage students to get integrated into the programme.

- Again, there is the need to provide teaching/learning materials on time and intensify pre-entry counseling for both tutors and students. This will help tutors and students to establish a foundation for the teaching and learning environment.

- The centre should create a course website to aid online chats. This will encourage frequent interactions between the students and the centre so that issues can be discussed promptly to prevent frustrations that will lead to attrition.

- The centre should also develop group projects and assignments that encourage students to develop relationships with other members within and outside their study centre, so that they can explore their knowledge base together. This group project may help students overcome physical separation, feeling of isolation, lack of support and feeling disconnected. Thus, reducing attrition levels.

- Furthermore, the centre should provide online access to a variety of services including assessments, educational counseling, registration, technical support, study skills assistance, career counseling, library services, students' rights and responsibilities and governance.

- Finally, there should be an opening forum in all the centres where students' concerns could be addressed.

\section{References}

Andrah, R. (2000). Profile of Distance Education Students at the University College of Education, Winneba. Journal of Educational Management, 4: 114-136. 
Ansere, J. (1976). Some Characteristics of Correspondence Students in Ghana. Unpublished

Doctoral Dissertation. Madison: University of Wisconsin.

Akuamoah-Boateng, C., Sam-Tagoe, J., \& Brown, P. (2010). Issues, prospects and challenges in practicum organisation for teachers on the distance mode of education: The case of University of Cape Coast. Teacher Education Conference and Proceedings (July, 2010), pp.97-106.

Benakani, V. A. (2009). Models and methods of teaching. New Delhi: Anmol Publications, PVT. LTD.

Bernard, R. M. \& Amundsen, C. L. (1989). Antecedent to dropout in distance education: Does One model fit it all? Journal of Distance Education, 4 (2), 25 - 46.

Brookfield, S. D. (1987). Teacher roles and teaching styles. In: C. Titmus (Ed). Lifelong Education for Adults - An International Handbook. New York: Pergamon Press pp. $209-212$.

Brown, P., \& Koomson, A. K. (2009). Widening access to quality higher education in developing countries. Report, Summaries, and Papers Fourth Edition. Raleigh: Carolina State University.

Carr, S. (2000). As distance education comes of age, the challenge is keeping the students. The Chronicle of Higher Education, 46(23), p. A39.

Chyung, Y., Winiecki, D., \& Fenner, J. (1998). A case study: Increase enrolment by reducing dropout rates in the distance education. Distance Learning, 98. Proceeding of the Annual Conference on Distance Teaching and Learning, Madison, W1, August 5-7

Cross, P. K. (1981). Adults as learners. San Francisco: Jossey Bass.

Cullen, M. 1994. Weighing it up: A case study of discontinuing access students. Occasional Papers Series: No.2. Edinburgh University, Centre for Continuing Education. Dagger, D., \& V. P., (2004) Evaluation of Adaptive Course Construction Toolkit

(ACCT), [viewed 24/11/2005] http://wwwis.win.tue.nl/-acristea/AAAEH05/papers/6-a3eh daggered IOS format v1.1.pdf

Fan, R. \& Chan, M.(1997). A study on the dropout in the mathematics founding courses. Paper presented at the $11^{\text {Th }}$ Annual Conference of the Asian Association of Open Universities, Malaysia.

Garrison, D.R.(1987). Reaching drop-out in distance education. Distance Education, 8(1), 95 $-101$

Huang, Y. (2004) a Model for Sustainable Student Retention : A Holistic Perspectives in the Student Dropout Problem with Special Attention to e-learning. DEOSNEWS, Volume 13 (5) [viewed30/10/2005] http://www.ed.psu.edu.acsde/deos/deosnews/deosnews13 5 pdf

Keegan, D. (1988). The foundations of distance education. London: Groom Helm.

Knowles, M. S., Holton, E. F., \& Swanson, R. A. (1998). The adult learner: The definitive classic In adult education and human resource development $\left(5^{\text {th }}\right.$ ed.). Houston: Guilt Publishing.

Lowe, S .D (2005) Responding to Learners Needs in Distance Education: Providing Academic and Relational Support (PARS). In S.J. Levine (Ed.), Making distance education work: Understanding learning and learners at a distance (pp 73-87). Okemos, MI: Learner Associates.net

Makau, B.(1993). The external degree programme at the University of Nairobi. In H. Perraton (Ed.), Distance education for teacher training (pp. 316-348). London: Routledge.

Minich, E. (1996). Using student's feedback to improve distance education. Florida Community College: Jacksonvill (ERIC No. ED 397893).

Morgan, C. K. \& Tam, M. (1999). Unraveling the complexities of distance education students' 
Moxley, J., (2006). Teaching wiki. University of South Florida. Retrieved January 31, 2006, from http://teachingwiki.org

Nash, R. (2004). Distance education: Why are the attrition rates so high? The Quarterly Review of Distance Education, 5 (3), 205-210.

Oztok, M. \& Brett, C. (2011).Social presence and online learning: A review of research. The Journal of Distance Education, 25(3), 21-37.

Parker, A. (1999). A study of variables that predict dropout from distance education.

International Journal of Educational Technology, 1 (V2), 55 - 61.

Perraton, H. (1992). Teacher education through distance learning: technology, curriculum, evaluation, cost, Parris: UNESCO.

Phipps, R., \& Merisotis, J. (1999). What's the difference? A review of contemporary research on the effectiveness of distance learning in higher education. Washington, DC: The Institute for Higher Education Policy.

Phythia, T. \& Clement, M.(1980). Post founding tutorial planning. Teaching at a distance, 18, 38- 43.

Rekkeda, T. (1983). Enhancing student progress in Norway. Teaching at a Distance, 233, 19 24.

Rickinson, B. \& Rutherford, D. (1996). Systematic monitoring of the adjustment to university undergraduate: a strategy for reducing withdrawal rates. British Journal of Guidance \& Counseling, 24(2), 213-232.

Roberts, T. (2006). Online collaborative learning in higher education, blog. Central Queensland University. Retrieved January 31, 2006, from http://clp.cqu.edu.au

Rovai, A.P. (2003). In search of higher persistence rates in distance online programmes. The Internet and Higher Education, 6(1)1-16

Students Assessment and Records Unit Report. (2009). Centre for continuing education. Cape Coast: University of Cape Coast.

Thompson, E. (1997). Can the distance education student progress (DESP) inventory be used as a tool to predict attrition in distance education? Higher Education Research \&Development, 18: $77-84$.

Tinto, V. (1982). Dropout from higher education: A theoretical synthesis of recent research. Review of Educational Research, 45 (1), 89 - 125.

Wojciechowski , A. \& Palmer, L.B. (2005). Individual student characteristics: Can any be predictors of success in online classes? Online Journal of Distance Learning Administration, VII (II), 1-20. 